\title{
HANS-GEORG GADAMER. DEFENSA DE LA RETÓRICA: DE LA DIALÉCTICA A LA HERMENÉUTICA*
}

\author{
Carmen Segura Peraita \\ Universidad Complutense de Madrid
}

\begin{abstract}
RESUMEN. El objetivo de este trabajo es analizar la vinculación de la hermenéutica gadameriana de la retórica y de la filosofía práctica, así como su crítica a la dialéctica monológica. Para ello se tiene particularmente en cuenta la relación mantenida por Gadamer con los planteamientos de Platón, Aristóteles y también Hegel. Por una parte, en la filosofía práctica aristotélica Gadamer encuentra una posibilidad de ampliación del modelo de verdad; por otra, entiende que el giro hermenéutico se basa en el paso de la dialéctica monológica a la dialéctica del diálogo. De acuerdo con este planteamiento la investigación se articula en torno a las siguientes cuestiones: la relación entre retórica y hermenéutica, la confrontación entre dialéctica y hermenéutica y la transformación de la dialécrica monológica en una dialéctica del diálogo. Al final, se formulan algunas conclusiones provisionales relativas al alcance y sentido de la hermenéutica filosófica.
\end{abstract}

Sólo una conciencia científica exacerbada hasta la ceguera puede ignorar que el debate sobre los verdaderos fines de la sociedad humana, o la pregunta por el ser en el pleno predominio del hacer, o el recuerdo de nuestro origen histórico y de nuestro futuro dependen de un saber que no es ciencia, pero que dirige la praxis de la vida humana.

* Este trabajo ha sido posible gracias al proyecto PB97-0302 (MEC).

1 H.-G. GADAMER, "Réplica a Hermenéutica y critica de la ideología (1971)", en Verdad y método II, Sígueme, Salamanca, 1994, trad. Manuel Olasagasti, pp. 243-66, 243. 
Lo que de verdad y en el fondo importa es el debate en torno a los verdaderos fines de la sociedad; saber cómo y en qué sentido comprometemos nuestra humanidad; hasta qué punto arriesgamos y hasta qué límite estamos autorizados a hacerlo. Esto resulta especialmente necesario cuando lo que nos jugamos no es sustituible; cada ser humano es un fin en sí mismo, no un objeto del que instancias anónimas o públicas puedan disponer a su antojo.

Desde los orígenes de la retórica se conoce bien la eficacia del recurso a los afectos. Con frecuencia han sido los sofistas quienes lo han explotado con mayor éxito. Por eso tendemos a rechazar, por sospechosa, cualquier afirmación que implique los sentimientos o, sin más, las buenas intenciones. Sin embargo, a pesar del constante peligro del abuso sofístico y/o ideológico, es preciso poner de relieve la ineludible dimensión ética y política del ejercicio de la filosofía. Hans-Georg Gadamer fue consciente de modo singular de las imponentes consecuencias sociales, humanas, de la actividad de pensar y, en términos generales, de conocer. Se percató con singular profundidad del modo en que una determinada concepción del conocimiento y de la ciencia ha influido en la idea que los seres humanos tenemos de nosotros mismos y de cómo ha modificado nuestro modo de actuar; supo ver la vinculación existente entre ciencia, técnica, poder y dominación; no quiso ser fatalista ni profeta de calamidades, aunque dudó de las posibilidades de la ciencia para autolimitarse. Por eso, confió a nuestra capacidad humana y política global la responsabilidad de hacer una aplicación razonable del saber científico y tecnológico ${ }^{2}$.

Por el momento, las calamidades no cesan de sucederse, y la disposición para hacer una aplicación humana de la técnica y la ciencia por parte de quienes detentan el poder continúa siendo, cuando se da, una excepción. Habitualmente, la toma de decisiones no está en manos de los filósofos, y la experiencia parece indicar que es mejor y deseable que continúe siendo así. La tarea de los pensadores, y también la de los meros profesionales de la filosofía, es la reflexión. No es menester que se dediquen a cuestiones vinculadas con la ética o la política de manera directa, aunque muchos de ellos lo hagan y hacerlo sea necesario y bueno. Lo que es preciso es que la persuasión de que la teoría es acción, de que también con las

2 Cfr. H.-G. Gadamer, "Lenguaje y comprensión (1970)", en Verdad y método II, op. cit., pp. 181-94, 190. 
palabras hacemos cosas, se transforme en certeza responsable. Hans-Georg Gadamer, el pensador que vivió el siglo XX, constituye - más allá de sus aciertos o desaciertos, de las opiniones de sus seguidores o detractores - un ejemplo paradigmático de actividad filosófica libre y responsable. Atreverse a saber comporta riesgos reales, especialmente para quien se decide a hacerlo; encontrar en la búsqueda del saber que la justifica el compromiso humano - público y social- constituye un descubrimiento auténtico. Realizar ambas cosas da razón de una vida dedicada a la tarea inacabada e inacabable del filosofar. Todo parece indicar que Hans-Georg Gadamer cumplió aquello que buscó: el diálogo en el que lo que importa no son los intervinientes ni sus necesidades psicológicas, sino la cosa misma.

\section{Sabiduría práctica. Retórica y hermenéutica}

Por su propia índole, la crítica emprendida por Gadamer al modelo moderno de ciencia se constituye en una reflexión ético-política que compromete al conjunto del saber filosófico. Sin embargo, no se puede decir que sus planteamientos sean los de un politólogo, un sociólogo o un filósofo moral y político. La hermenéutica filosófica se reivindica como un saber de totalidad que aspira a trascender los límites de aquella metafísica que se ha constituido en condición de posibilidad de la tecnociencia actual. Así, parece que al confrontarse con la filosofía primera se sitúa en el mismo plano, de modo que su propuesta ostentaría la misma radicalidad que aquélla ha reclamado desde siempre para sí. No se trata, desde luego, de que la hermenéutica se comprenda a sí misma como una nueva forma de superación, porque, si lo hiciera, se inscribiría de inmediato dentro de la dinámica que ha caracterizado a la metafísica occidental; lo que pretende el pensador de Heidelberg, por el contrario, es destacar algo que hasta el momento había sido ignorado: la universalidad y originariedad de la lingüisticidad humana y, con ella, de la comprensión ${ }^{3}$. Ahora bien, si esto último es así, puede resultar difícil entender cómo se ha de conciliar el pretendido carácter teórico de esta empresa con el supuesto carácter práctico de la reflexión ético-politica a la que se acaba de hacer referencia al comenzar este párrafo.

3 "La universalidad de la lingüisticidad humana como un elemento sin fronteras que todo lo sustenta, no sólo la cultura transmitida por el lenguaje, sino absolutamente todo, porque todo se inserta en la comprensibilidad de las relaciones mutuas». H.-G. GADAMER, «Retórica, hermenéutica y crítica de la ideología. Comentarios metacríticos a Verdad y método I», en Verdad y método II, op. cit., pp. 225-52, 230. 
Uno de los motivos por el que esta conciliación resulta dificultosa es que, por tradición, acostumbramos a distinguir dos ámbitos bien definidos para el pensamiento: el de la razón teórica y el de la razón práctica. También por tradición, acostumbramos a situar los diferentes objetos de la filosofía - sus cuestiones propias- en el terreno que suponemos les corresponde. Así pues, entendemos que hay, por una parte, cuestiones especulativas y, por otra, cuestiones prácticas. No tiene sentido dudar de la operatividad de un modo de proceder que se remonta a la distinción aristotélica entre lo que es siempre y necesariamente -el universo, objeto de la ciencia y la sabiduría- y lo que no es ni siempre ni necesariamente -la acción humana, objeto de la ética y la política-. No obstante, como puso de relieve Heidegger, el problema que plantea esta separación es el que se deriva de haber otorgado la primacía a la teoría frente a la acción. De este modo, lo humano habría pasado a situarse en un segundo plano debiendo, además, desenvolverse de manera forzada dentro de los márgenes establecidos por la sabiduría. Kant intentó solventar los problemas de esta comprensión otorgando la prioridad a la razón práctica frente la teórica; sin embargo, esto significa la aceptación de la distinción y, con ella, la continuidad de la separación entre saber teórico y saber práctico. Pues bien, a lo largo de estas páginas se evidenciará cómo en el proyecto gadameriano se realiza la posibilidad de una teoría no desvinculada de la acción.

Es sabido que el modelo cartesiano de ciencia se impuso de modo rotundo en la modernidad hasta lograr que sólo aquello que es reiterable y verificable experimentalmente alcance a nuestros ojos el estatuto de verdadero. Tal concepción reduccionista de la verdad conduce a una lamentable limitación del mundo humano: lo verdadero queda limitado a lo empíricamente posible (en el sentido de factible); por tanto, a lo que se puede experimentar o hacer de forma controlada. Así es como la ciencia acaba reduciéndose a técnica, y como ésta se transforma, en definitiva, en poder. Ésta es la vía que conduce de la verdad científica a la verdad del poder; es decir, al poder como criterio de verdad.

En esta situación, la propuesta de ampliación de la idea de verdad constituye un poderoso revulsivo que es, a la vez, teórico, ético y político. De hecho, la intención de Gadamer fue mostrar que la verdad no se puede constreñir al estrecho ámbito de la razón teórica, sino que, por el contrario, incluye en sí, y de manera eminente, lo que es propio de la razón práctica: la verdad que comparece y se constituye en y por la acción humana. No se trata tan sólo de conceder 
que a las verdades científicas convendría, por humanidad, añadir las prácticas; se trata de hallar una noción de verdad acorde con lo que somos y con el mundo en el que somos.

Así, la dificultad que se plantea de modo inmediato es la de saber cómo y en qué medida comparece, cómo se muestra y cómo se dice tal verdad. Esta pregunta resulta especialmente pertinente si, con Heidegger y desde él, se parte de que la verdad no es presencia pura, de que también la verdad posee su propia temporalidad y que a ella le pertenece su situación hermenéutica ${ }^{4}$. A juicio de Gadamer, no todo está ahí delante, de forma que se pueda proponer sin residuos en el discurso; por el contrario, hay también lo que es y se percibe pero que no es susceptible de comparecer en el discurso lógico-demostrativo. La razón de esto último estriba, a su juicio, en la esencia desocultadora-ocultadora del lenguaje; es ella la que exige ir más allá de la lógica enunciativa y «buscar horizontes más amplios" ${ }^{5}$. Como ya se ha recordado, el discípulo de Heidegger cree encontrar en la hermenéutica filosófica esa posibilidad de ir más allá. Ésta sería la que, en definitiva, podría satisfacer las exigencias de un saber que no es ciencia pero que, por su índole peculiar, se compadece con la praxis de la vida humana.

Gadamer consideró que para el propósito de recuperar el legado socrático de una sabiduría humana, la filosofía práctica de Aristóteles podría servirnos de modelo ${ }^{6}$. De acuerdo con esta sugerencia, a lo largo de este apartado se atenderá de manera especial a la relación entre la hermenéutica gadameriana y la filosofía práctica aristotélica. Lo cierto es que no se trata de algo meramente coyuntural, puesto que como también afirmó Gadamer, la hermenéutica y la filosofía griega habían sido los dos puntos básicos de su labor ${ }^{7}$. En realidad habría que atreverse a precisar esta expresión, ya que no se trató de dos puntos sino de uno

4 "Lo que queremos expresar con la verdad - apertura, desocultación de las cosas- posee, pues, su propia temporalidad e historicidad». H.-G. GADAMER, "¿Qué es la verdad?», en Verdady método II, op. cit., pp. 51-62, 62. De hecho, Gadamer afirma también que «no es posible avanzar en el conocimiento sin dejar a trasmano una posible verdad (...). No es sólo que siempre encubramos y olvidemos la verdad al tiempo que la conocemos, sino que chocamos forzosamente con los límites de nuestra situación hermenéutica cuando buscamos la verdad". Ibid., 57.

5 H.-G. GADAMER, «Lenguaje y comprensión", op. cit., 194.

${ }^{6}$ Cfr. H.-G. GadAMER, "Autopresentación de Hans-Georg Gadamer», en Verdad y método II, op. cit., pp. 375-402, 394.

${ }^{7}$ Cfr. ibid., 389. 
solo o, si se prefiere, de dos líneas de fuerza orientadas en la misma y única dirección.

Pues bien, el autor de Verdad y método encuentra en la retórica un singular reconocimiento y tratamiento de una idea de verdad no cientificista ${ }^{8}$. Que esto es así se pone claramente de manifiesto al recordar las palabras con las que el mismo Gadamer vincula ambas disciplinas:

¿Dónde insertar la reflexión teórica sobre la comprensión sino en la retórica, que es desde la más antigua tradición el único abogado de un concepto de verdad que defiende lo probable, el eikós (verosimile) y lo evidente a la razón común contra las pretensiones de demostración y certeza de la ciencia? Convencer $y$ persuadir sin posibilidad de una demostración es la meta y la pauta de la comprensión y la interpretación no menos que la retórica y la oratoria?.

Todavía en 1969 el mismo Gadamer admitía que la cuestión acerca de si la correspondencia entre retórica y hermenéutica era total y plena estaba pendiente de resolución, pero entendió que esto no era obstáculo para resaltar los aspectos esenciales que ambas tenían en común. Como ya se ha mostrado en el texto que se acaba de citar estos serían los tres siguientes: 1) la hermenéutica compartiría con la retórica «la delimitación frente al concepto de verdad de la teoría de la ciencia y la defensa de su derecho a la autonomía” ${ }^{10}$. 2) Esto mismo implica, como también se ocupó de admitir Gadamer, que ambas «se caracterizan por una cierta ambigüedad de su pretensión científica, determinada en parte por la relación con la práctica” ${ }^{11}$. 3) Por último, lo anterior significa que el ámbito propio de ambas disciplinas es el de los argumentos persuasivos y no lógicamente concluyentes ${ }^{12}$.

${ }^{8}$ Como es sabido, fue Aristóteles quien - tras las primeras elaboraciones platónicas- se ocupó definitivamente de su fundamentación. Gadamer recuerda que el Estagirita no sólo escribió la primera historia de la retórica sino que desarrolló la teoría acerca de ella. Cfr. H.-G. GADAMER, "Retórica, hermenéutica y crítica de la ideologia», op. cit., 227.

9 Ibid., 229.

${ }^{10}$ H.-G. GADAMER, «Hermenéutica (1969)», en Verdad y método II, op. cit., pp. 363-74, 368.

${ }^{11}$ H.-G. GADAMER, «Retórica, hermenéurica y crítica de la ideologia", op. cit., 227.

12 Cfr. H.-G. Gadamer, "Réplica a Hermenéutica y critica de la ideologia", op. cit., 263. 
Teniendo en cuenta el interés de Gadamer por destacar la relación entre ambas disciplinas, nada tiene de extraño que hiciera remontar los orígenes de la hermenéutica a los mismos de la retórica ${ }^{13}$. De hecho, sostuvo que la historia de aquélla es tan antigua y honorable como la de ésta (tanto que para dar cuenta del nacimiento de la hermenéutica nos tendríamos que remontar hasta Ulises e incluso hasta el Néstor de la Iliada). Desde luego, el autor de Verdad y método admitió que, en sentido estricto, la hora de la hermenéutica no llegó hasta la modernidad $^{14}$, pues «no es de extrañar que al pasar a una cultura más alfabetizada la retórica fuera siendo sustituida poco a poco por la hermenéutica, por el interés por interpretar textos" ${ }^{15}$. No se puede olvidar que el modelo más próximo de retórica en el que Gadamer se basa para sus desarrollos no es el aristotélico sino el humanista. En cualquier caso parece también claro que el autor de Verdad y método quiso mantener la vinculación entre su propuesta hermenéutica y aquella antigua y singular retórica fundada por Aristóteles.

Pues bien, por lo que respecta a uno de los principales intereses gadamerianos, el de evitar que la ciencia se extralimite en sus pretensiones metodológicas y demostrativas, ya Aristóteles advirtió que no se puede pretender el mismo rigor para todos los razonamientos y que ues propio del hombre instruido buscar la exactitud en cada materia en la medida en que la admite la naturaleza del asunto; evidentemente, tan absurdo sería aceptar que un matemático empleara la persuasión como exigir de un retórico demostraciones» ${ }^{16}$.

En este texto de la Ética a Nicómaco, Aristóteles parte de una convicción que para él no es objeto de discusión: que las demostraciones no pertenecen a la retórica y que buscarlas dentro de su ámbito sería absurdo. Es esta convicción la que, tomada como punto de partida, le permite explicar al Estagirita que es absurdo buscar el mismo tipo de rigor para los diferentes ámbitos de saber. También es

13 Por su parte, Ricoeur ha recordado que «la retórica es la disciplina más antigua del uso discursivo del lenguaje. Nace en Sicilia en el siglo VI antes de nuestra era". P. RICOEUR, "Retórica, poética y hermenéutican, en G. Aranzueque (ed.), Horizontes del relato. Lecturas y conversaciones con Paul Ricoeur, Cuaderno Gris, 1997, Vicedecanato de la Facultad de Filosofía y Letras de la U.A.M., pp. 79-90, 80.

${ }_{14}$ Cfr. H.-G. GADAMER, "Retórica, hermenéutica y crítica de la ideología», op. cit., 228.

15 H.-G. GADAMER, "La hermenéutica de la sospecha», en G. Aranzueque (ed.), Horizontes del relato, op. cit., 128.

16 ARISTÓTELES, Etica a Nicómaco 1094b, 14-1095a 1. 
esta misma razón básica la que autoriza a Gadamer a defender lo probable y, por tanto, a intentar limitar las pretensiones universalistas de la ciencia ${ }^{17}$. Sólo de este modo, en opinión de los autores de la Retórica y de Verdad y método, será posible mantener el ámbito propio de la pólis y de la actividad que le es propia.

No es necesario volver a insistir en la importancia de una cuestión a la que ya se ha hecho referencia al comienzo de este trabajo: de lo que se está tratando es de custodiar lo que tiene que ver con los verdaderos fines, con los auténticos bienes. En este marco se puede advertir toda la trascendencia de la vieja pregunta griega acerca de cuál es el mayor bien del ser humano y cuál es el camino para alcanzarlo. También en la Ética a Nicómaco Aristóteles se plantea esta cuestión aunque, como es sabido, su respuesta no es unívoca. Por una parte sostiene que, en cuanto que busca el fin, lo bueno y lo mejor para el ser humano, la política ha de ser la ciencia o facultad suprema y directiva en grado sumo ${ }^{18}$. Por otra parte y en el mismo tratado, sostiene que puesto que el ser humano no es lo mejor del cosmos «sería absurdo considerar la política o la prudencia como lo más excelente»" ${ }^{19}$. Desde luego, ambas afirmaciones podrían parecer contradictorias si no se tuviera en cuenta que, según la precisión del mismo Estagirita, esta vez en el libro IV de la Metafisica, no se dicen en el mismo sentido. Así, en cuanto al bien del ser humano, la política ha de ser directiva; en cuanto a lo mejor del cosmos, lo ha de ser la sabiduría, que es ciencia e intelecto de lo más honorable.

Bien mirada, la respuesta aristotélica a la pregunta por lo mejor no llega a satisfacer plenamente. Pero, en cualquier caso, se ha de admitir que su conclusión no fue fruto de una decisión arbitraria; por el contrario, diferenció dos ámbitos y en cada uno reconoció un tipo de supremacía: la política y con ella la retórica - y con Gadamer, habríamos de concluir nosotros, la hermenéutica - sería directiva con relación a un ámbito de objetos; la sabiduría y con ella la ciencia, del otro ámbito de objetos. Pero lo cierto es que esto no es todo. Por una parte,

${ }^{17}$ Quintín Racionero ha insistido en que el estatuto ontológico de la retórica aristotélica es el de lo meramente posible, sobre el que se asientan los argumentos de probabilidad, y en que lo posible (lo dynatón) es lo que puede ser de dos o más maneras. A su vez, éste es precisamente el ámbito de la phrónesis, de la sensatez por la que el hombre juicioso guía sus elecciones; el ámbito de la ética y de la política. Cfr. Q. RACIONERO, “Introducción» a la Retórica de Aristóteles, Gredos, Madrid, 1994, pp. 7-152, 126-36.

${ }^{18}$ Cfr. ARISTÓTeles, Ética a Nicómaco, 1094a 18-1094b 1.

${ }^{19}$ Ibid., 1141 a 21. 
hay que tomar en consideración la crítica de Martín Heidegger: a su juicio, Aristóteles habría acabado por primar la sabiduría sobre la prudencia; además, este primado se mantuvo a lo largo de toda la historia de la metafísica occidental. Por tanto, la decisión del Estagirita habría sido la última responsable del moderno predominio de la ciencia. Como tendremos oportunidad de ver más adelante, parece que Gadamer compartió esta convicción heideggeriana. Desde luego, éste no es el momento para revisar la crítica del pensador de Friburgo. Por el momento habremos de limitarnos a reconocer que mediante la política y, por tanto, mediante la retórica, Aristóteles reserva un ámbito de reflexión especial que reconoce no sujeto a las leyes de la ciencia ${ }^{20}$. Por otra parte, lo que se desprende de la conclusión anterior es que Aristóteles habría acabado por separar dos ámbitos que en lo sucesivo se habrían de considerar incomunicables: el de la teoría y el de la acción. Todo parece indicar que esto no resulta suficientemente satisfactorio, pero al menos garantiza, como ya se ha señalado, la inmunidad de los asuntos humanos frente a las pretensiones de la ciencia.

Sea como fuere, cuando se trata de defender los derechos de la praxis, parece que Gadamer no encuentra un serio obstáculo en las observaciones realizadas por Heidegger; por el contrario, todo parece indicar que el terreno despejado por Aristóteles le resulta suficiente para realizar su defensa de ese ámbito especial de reflexión que no se encuentra sometido a las leyes de la ciencia ${ }^{21}$, al que se acaba de hacer referencia. Un ámbito que actualmente corresponde salvaguardar, según parece desprenderse del planteamiento gadameriano, a la hermenéutica filosófica.

Para mostrar esto último y tomando como punto de partida la distinción aristotélica entre el saber técnico, el productivo y el práctico ${ }^{22}$, el pensador de Heidelberg se pregunta por la naturaleza del saber previo que permitió al Estagirita realizar esas distinciones. Su respuesta es que "pese a que éste [Aristóteles] destacó con precisión la estructura del saber práctico frente a la estructura del saber técnico, quedó sin repuesta, una vez más, la pregunta: ¿qué género de saber es el que llevó a Aristóteles a encontrar y enseñar tales distinciones? ¿Qué género de saber es, a su vez, la ciencia práctica (y política)?” ${ }^{23}$. Gadamer entendió que

${ }^{20}$ Cfr. Q. RaCIONERO, op. cit., 130.

${ }^{21}$ Cfr. ibid.

22 "Todo pensar discursivo es o práctico o productivo o teórico". ARISTÓTELES, Metafisica VI, $1025 b 24-5$.

${ }^{23}$ GADAMER, H.-G., "Réplica a Hermenéutica y critica de la ideologia», op. cit., 244-5. 
se trataba de «un saber general, pero de un saber que se puede calificar menos de saber productivo que de crítica" ${ }^{24}$. Precisamente lo mismo que, a su parecer, "parece ocurrir con la hermenéutica filosófica» ${ }^{25}$.

A la hora de justificar la pertinencia de este paralelismo, el autor de Verdad $y$ método recurre a una serie de argumentos que, a continuación, se exponen de manera sintética. En primer lugar, Gadamer recuerda que hermenéutica significa comprensión; que en la filosofía práctica de Aristóteles la comprensión se denomina sýnesis y, por último, que ésta ha de ser entendida como una modificación de la racionalidad práctica ${ }^{26}$. Por otra parte, Gadamer sostiene que, como sucede con la filosofía práctica, «tampoco el arte de la interpretación y de la comprensión [al igual que en la retórica] es una destreza específica que se puede estudiar y aprender para llegar a ser una especie de intérprete profesional ${ }^{27}$; por el contrario, pertenecería al ser humano como tal. Más aún, a su juicio, la comprensión y el acuerdo uson la forma efectiva de realización de la vida social (...). Nada queda excluido de esta comunidad de diálogo, ninguna experiencia del mundo" ${ }^{28}$. En tercer lugar y para finalizar, nuestro pensador insiste en que la hermenéutica filosófica es un saber general, universal, que viene a satisfacer la nece-

24 Ibid., 245. Respecto al peculiar estatuto teórico-práctico de la filosofía práctica aristotélica, Gadamer afirma también lo siguiente: "Conviene recordar aquí el rango peculiar que posee la filosofía práctica en Aristóteles. Se llama philosophía y esto limita su interés "teórico" y no práctico; pero no se cultiva por el mero deseo de saber, como señala Aristóteles en su Ética, sino de cara a la areté, es decir, con miras al ser y el obrar práctico. Ahora bien, me parece muy significativo que se pueda afirmar otro tanto de lo que Aristóteles llama en el libro VI de la Metafisica "poietikè philosophia" y que abarca tanto la poética como la retórica. Ni una ni otra son variedades de la téchne en el sentido de saber técnico. Ambas se basan en una facultad universal del ser humanom. Ibid., 280.

${ }^{25}$ Ibid., 245.

${ }^{26}$ Con relación a la sýnesis, cfr. también GADAMER, «Aristoteles und die imperativische Ethik», en Gesammelte Werke, 7, Grieschische Philosophie III, Mohr Siebeck, Tubinga, 1991, pp. 381-95, 391-2. Además: "Algo quiere decir el hecho de que la palabra griega que designa el comprender y la comprensión, sýnesis (...), represente en el contexto de la ética aristotélica una especie de virtud intelectual (...). La "comprensión" designa entonces una modificación de la racionalidad práctica». H.-G. GADAMER, "La hermenéutica como tarea teórica y práctica (1978)», en Verdad y método II, op. cit., pp. 293-308, 305-6.

${ }^{27}$ H.-G. GADAMER, «Retórica y hermenéutica (1976)", en Verdad y método II, op. cit., pp. 267$82,281$.

${ }^{28}$ H.-G. GADAMER, "Réplica a Hermenéutica y critica de la ideologia», en Verdad y método II, op. cit., 247. 
sidad de recuperar el "legado socrático de una "sabiduría humana" que en comparación con la infalibilidad semidivina del saber científico es una nesciencia»" y que, como se acaba de ver, puede y debe amoldarse al modelo de la filosofía präacticà aristotélica.

Los argumentos que se acaban de recordar justifican la equivalencia entre hermenéutica y saber general. Sin embargo, la principal tesis gadameriana en la que se asienta este paralelismo continúa ofreciendo dificultades. Es la que se refiere a ese supuesto saber general aristotélico. Por una parte, Gadamer sostiene que ese saber general es el que, con su carácter previo, permite a Aristóteles diferenciar theoria, poiesis y prâxis; por otra, responde también que la ciencia práctica y política es ese saber general. Pues bien, hasta donde sabemos, el único saber general que reconoce y al que se refiere Aristóteles es la dialéctica. Sin embargo, como tendremos oportunidad de analizar, Gadamer no parece dispuesto a dar cabida a la dialéctica dentro de la hermenéutica. Por otra parte, es posible pensar que el autor de Verdad y método esté suponiendo la operatividad de un saber general de tipo socrático, no tematizado de manera directa por Aristóteles. Precisamente, éstas son las cuestiones que serán abordadas en el siguiente epígrafe.

\section{Sabiduría de reflexión crítica. Dialéctica y hermenéutica}

En las líneas anteriores se han recordado algunos de los argumentos de los que se sirve Gadamer para otorgar a la hermenéutica filosófica las mismas características - y en consecuencia, el mismo cometido- que él reconoce como propias de la filosofía práctica aristotélica. Ahora bien, Gadamer no se satisface con establecer el estatuto de saber práctico que es propio de la hermenéutica, o mejor, su vecindad con la filosofía práctica de Aristóteles. Además, y frente a sus contradictores, el autor de Verdad y método afirma que esa hermenéutica filosófica es un saber crítico que "aspira, como dice Habermas, a un "saber de reflexión crítica" ${ }^{30}$.

29 H.-G. GADAMER, "Autopresentación", en Verdad y método II, op. cit., 394. Respecto a la filosofía práctica de Aristóteles cfr. también H.-G. GADAMER, "Die sokratische Frage und Aristoteles", en Gesammelte Werke 7, op. cit., pp. 373-80.

30 H.-G. GADAMER, "Réplica a Hermenéutica y critica de la ideologia», en Verdad y método II, op. cit., 246. 
En "Réplica a Hermenéutica y crítica de la ideologia», Gadamer expone varios ejemplos concretos de la actividad crítica que, a su juicio, ha desempeñado la hermenéutica filosófica: el descubrimiento del objetivismo ingenuo al que está encadenada la autocomprensión de las ciencias históricas que se orientan por las de la naturaleza; el haber desvelado las falsas objetivaciones de las palabras, en línea con Wittgenstein; la defensa del lenguaje comprensible frente a determinadas pretensiones de la lógica; la crítica a la aplicación de métodos inadecuados en las llamadas ciencias del espíritu.

No cabe duda de que la hermenéutica filosófica ha llevado a cabo tal tarea crítica, pero la cuestión teórica que se plantea de manera inmediata es la de si un saber práctico como el perfilado por Gadamer, puede ser a la vez crítico.

De acuerdo con Aristóteles, el saber práctico es el propio de la phrónesis, de la política, de la poética y de la retórica. Por el contrario, el saber crítico - bien es cierto que en el mismo plano que la ciencia- es el propio de la dialéctica. En este sentido y ahora de acuerdo con el Fedro, la retórica habría de ser sometida a la dialéctica, entendida como sabiduría suprema, como ciencia del bien; de hecho, fue en ella donde Platón encontró la salvaguarda contra los abusos «retóricos" de los sofistas. Por tanto, habría que concluir que tanto Platón como Aristóteles se vieron en la necesidad, aunque por razones y comprensiones diferentes, de limitar la retórica y de recurrir a la dialéctica. Sin embargo, se acaba de recordar que Gadamer parece rechazar la dialéctica de forma tajante. Así las cosas, todo parece indicar que, a pesar de la autovinculación gadameriana con la filosofía griega, hay algo que singulariza su propuesta y que quizá la haga irreductible tanto a los planteamientos platónicos como a los aristotélicos.

De ese asunto tendremos que ocuparnos enseguida, pero no se puede olvidar que la pregunta que se ha planteado y que ha dado lugar a esta cuestión concreta es si corresponde a la hermenéutica filosófica el estatuto de saber de reflexión critica. Pues bien, dada la básica subsunción de la hermenéutica en la retórica surgen algunas dificultades que no se pueden ignorar. En primer lugar, hay que tomar en consideración tres problemas que han sido destacados por Ricoeur: el primero es el que tiene que ver con la pretensión de universalidad que es característica del planteamiento gadameriano y que, no sin razones, ha sido objeto de duras críticas. El segundo es el que se derivaría del supuesto y/o posible carácter coactivo del discurso retórico. Por último, si como propuso Gadamer la filoso- 
fía práctica de Aristóteles constituye el modelo, será preciso cuestionar - partiendo de las relaciones establecidas por el Estagirita entre retórica y dialécticala relación entre dialéctica y hermenéutica.

A continuación se abordarán brevemente los problemas relativos a lo que Ricoeur ha denominado "la reivindicación totalizadora de la retórica»" ${ }^{31}$. Pues bien, como reconoce el pensador francés, en principio no parece difícil aceptar que la argumentación haya de conquistar todo el campo de la razón práctica, puesto que nos movemos en el ámbito de lo preferible y esto es objeto de la deliberación; sin embargo, resulta más difícil admitir la presunción según la cual la retórica - y en nuestro caso, la hermenéutica - ha de abarcar todo el ámbito de la filosofía ${ }^{32}$. Entre otros, también Ricoeur ha señalado que la retórica es "un modo de razonamiento a medio camino entre la coacción de lo necesario y lo arbitrario de lo contingente» ${ }^{33}$; que la retórica se encuentra "a medio camino entre el discurso demostrativo y la violencia disimulada en el discurso puramente seductor ${ }^{34}$. Por una parte, resulta claro que no es discurso demostrativo puesto que, como es sabido, tiene que ver con la acción humana y por lo tanto, con lo probable y lo verosímil. Pero, por otra parte, es necesario admitir que tampoco es un "discurso puramente seductor", puesto que éste es el que elabora y despliega el sofista cuando pasa sin transición del arte de persuadir al de engañar, cuando se sirve de los prejuicios como si hubiera un acuerdo previo acerca de las ideas y cuando utiliza el arte de seducir en lugar de recurrir al de agradar ${ }^{35}$.

Lo cierto es que Ricoeur distingue bien entre el discurso del retórico y el del sofista; el problema estriba en que entiende que sobre la retórica se cierne lo que él denomina ula amenaza de la decadencia»: el de la caída en la sofística. No obstante, esto no parece constituir un problema grave para Gadamer, quien entendió que la retórica fue el resultado de la controversia mantenida

${ }^{31}$ P. RicoeUR, «Retórica, poética y hermenéutica», op. cit., 82.

${ }^{32}$ Cfr. ibid., 80ss. En concreto: «La retórica nunca ha dejado de oscilar entre la amenaza de decadencia y la reivindicación totalizadora en virtud de la cual pretende igualarse a la filosofia", ibid., 81.

${ }^{33}$ Ibid., 80.

${ }^{34}$ Ibid. Cfr. también el comentario a Ricoeur que en este mismo volumen realiza Aranzueque. G. ARANZUEQUE, "Retórica política y hermenéutica», en Horizontes del relato..., op. cit., pp. 369-88, 370-1.

${ }^{35}$ Cfr. RicoeUR, "Retórica, poética y hermenéutica", op. cit., 81. 
con la sofística y que la diferencia entre el sofista y el retórico fue claramente establecida por Aristóteles, especialmente cuando puso en la intención, en el tipo de vida elegido, la línea divisoria entre uno y otro ${ }^{36}$. Esto es lo que, en definitiva, le permite a Gadamer afirmar — también en esta ocasión con relación directa al maestro de Aritóteles- que «la diferenciación que el mismo filósofo hace del sofista, tal como nos enseña la Carta séptima y como demuestra el conjunto de la obra escrita de Platón, es el propósito jamás olvidado de su filosofar" ${ }^{37}$. Este propósito sería, por tanto, el conjuro infalible que, en opinión de Gadamer, libraría al retórico del recurso a lo que Ricoeur denomina la violencia del discurso.

Pero todavía cabe preguntarse si la intención o el propósito son suficientes para salvaguardar los derechos de la filosofía y si, a la vez, justifican la pretensión de universalidad de la que nos estamos ocupando. Para poder responder a esta última cuestión de manera cabal y así evitar el error de la precipitación, es preciso que entendamos bien en qué consiste dicha pretensión, ya que es posible que no se trate tanto de suplantar a otras disciplinas en sus ámbitos propios cuanto de encontrar aquello que, como señala Gadamer, «garantice una aplicación razonable de nuestro saber» en el terreno propio de la acción humana, que es su ámbito propio y el que, en definitiva, importa ${ }^{38}$. No obstante, como ya se ha señalado con anterioridad, parece que tal garantía sólo la puede ofrecer un saber de índole crítica con las características que Aristóteles reconoció en su día a la dialéctica. Por eso lo que sorprende, cuando menos, es que la apelación de Gada-

36 "Sin embargo, la sofística no [reside] en la facultad, sino en la intención. Y, por lo tanto, en nuestro tema, uno será retórico por ciencia y otro por intención, mientas que, en el otro caso, uno será sofista por intención y otro dialéctico, no por intención, sino por facultad". Aristóteles, Retórica I, 6, 1355b 18-24. También: "La sofística y la dialéctica discuten acerca del mismo género que la filosofía, pero [ésta] se distingue de la una por el alcance de su capacidad y de la otra por el tipo de vida elegido: y es que la dialéctica es tentativa y refutadora sobre aquellas cosas que la filosofía conoce realmente, y la sofística, por su parte, aparenta ser sabiduría, pero no lo es». ARISTÓTELES, Metafisica, 1004b 24-26. Respecto a GADAMER, cfr. "Logos und ergon im platonischen Lysis", en Gesammelte Werke, 6. Grieschische Philosophie II, Mohr Siebeck, Tubinga, 1985, pp. 171-86, 174.

37 Cfr. H.-G. GADAMER, «Zur Vorgeschichte der Metaphysik», en Gesammelte Werke, 6, op. cit., pp. 9-29.

"Yo no soy fatalista ni un profeta de calamidades por dudar de que la ciencia pueda autolimitarse. Lo que creo es que no será la ciencia sino nuestra capacidad humana y política global la que pueda garantizar la aplicación razonable de nuestro saber o, en todo caso, hacer que evitemos las catástrofes extremas». H.-G. GADAMER, «Lenguaje y comprensión», op. cit., 190. 
mer se dirija de manera exclusiva a la retórica y que, a la vez, cualquier vinculación con la dialéctica parezca, al menos inicialmente, estar ausente.

Estas últimas reflexiones conducen a la conclusión de que el problema relativo a la pretensión de universalidad únicamente encontrará una respuesta cuando hayamos podido resolver las dificultades relativas a la relación entre retórica, hermenéutica y dialéctica.

En el trabajo de 1969 titulado "Hermenéutica", Gadamer recuerda, en clara alusión a la concepción platónica, que entre retórica y dialéctica existe una barrera infranqueable.

El elemento de la retórica (...) parece dilatarse con el fenómeno universal de la comprensión y del entendimiento. Pero hay desde antiguo una barrera infranqueable entre la retórica y la dialéctica en el sentido antiguo de la palabra. El proceso de entendimiento actúa a mayor profundidad, en la esfera de la comunión intersubjetiva ${ }^{39}$.

Teniendo en cuenta que esta afirmación de incompatibilidad se realiza en el marco de una hermenéutica que, por otra parte, se remonta de forma explícita a Aristóteles, hay que admitir que resulta, cuando menos, sorprendente. Para amortiguar el impacto quizá convenga tener en cuenta que, como también ha sugerido Ricoeur, la palabra "dialéctica» es en sí misma fuente de mucha confusión. Según el pensador francés contamos con al menos tres modelos de dialéctica (los de Aristóteles, Kant y Hegel; al que habría que añadir el de Platón) y con varios submodelos (entre otros, a su juicio, los de Kierkegaard, Nietzsche o Heidegger). Por ello, y ya con relación a Gadamer, la pregunta concreta que quizá se habría de formular es ésta: ¿entre qué modelos de dialéctica y de retórica existe una barrera infranqueable? La necesidad de plantear esta cuestión se hace todavía más acuciante al tener en cuenta que, como ya se ha señalado, la referencia gadameriana a la crítica conlleva y reclama la toma en consideración de la dialéctica. Por otra parte, es preciso recordar que las notas distintivas y esenciales que Gadamer atribuye a la retórica — tales como la universalidad y el

${ }^{39}$ H.-G. GADAMER, "Hermenéutica», op. cit., 368-9. 
carácter no lógicamente concluyente de sus argumentos- se predican también de la dialéctica. De hecho, tal como lo entendió Aristóteles (cuya comprensión es objeto particular de estas reflexiones), retórica y dialéctica son antistróficas, lo que significa tanto como que, al menos de manera inicial, se exigen mutuamente.

Así es, el Estagirita considera que las dos formas de saber que nos ocupan, retórica y la dialéctica, son antistróficas o lo que es lo mismo, correspondientes. Por lo que respecta a la nota de universalidad, Aristóteles afirma que «la retórica es una antístrofa de la dialéctica, ya que ambas tratan de aquellas cuestiones que permiten tener conocimientos en cierto modo comunes a todos y que no pertenecen a ninguna ciencia determinada ${ }^{40}$. Por lo que se refiere al carácter no lógicamente concluyente de los argumentos, el Estagirita sostiene que lo propio de la retórica es "reconocer lo convincente y lo que parece ser convincente, del mismo modo que [corresponde a la dialéctica] reconocer el silogismo y el silogismo aparente" ${ }^{41}$. Además, todavía en este último orden de cuestiones, Aristóteles precisa que el arte de la retórica se refiere a las pruebas por persuasión y aclara que la persuasión es una especie de demostración (puesto que sobre todo nos persuadimos cuando creemos que algo está demostrado). Pues bien, a la forma de demostración más propia y firme de la retórica la denomina Aristóteles enthy$m e m a^{42}$ y de él dice que «es un silogismo y [que] sobre el silogismo en todas su variantes corresponde tratar a la dialécticas ${ }^{43}$. Así pues, también al incluir el enthy-

${ }^{40}$ ARISTÓteles, Retórica I, 1354a, 1-4 y Retórica, 1355b, 8-9. Además, ARISTÓTELes, Refutaciones sofisticas, 172a 12-15. Cfr. también Q. RACIONERO, "Introducción» a la Retórica, pp. 34ss y P. Ricoeur, "Retórica, poética y hermenéutica», op. cit., 80.

41 ARISTOTELES, Retórica I, 6, 1355b, 8-18. De acuerdo con la exposición de Racionero, la dialéctica conforma el instrumento general del saber para todas aquellas materias para las que no hay una ciencia determinada, mientras que la retórica, con su recurso a las deliberaciones, es el instrumento de análisis para los asuntos en cuyo marco de posibilidad interviene el ser humano. Cfr. Q. RaCiONERO, "Introducción» a la Retórica de Aristóteles, op. cit., 130.

42 "La demostración retórica es el enthymema y éste es, hablando en absoluto, la más firme de las pruebas por persuasión». ARISTOTELES, Retórica, 1355a, 8-9.

43 Ibidem, 1355a 4-10. De hecho, Aristóteles dedica el capítulo 27 del libro II de los Analíticos primeros al razonamiento probable. Alli afirma que «el razonamiento probable [enthymema] es un razonamiento a partir de verosimilitudes o signos». Ibid., 70a 2-3. Además, el Estagirita precisa que lo verosímil y el signo no son lo mismo y aclara que lo verosímil es una proposición plausible; «en efecto, lo que se sabe que la mayoría de las veces ocurre así o no ocurre así, o es o no es, eso es lo verosímil». Ibidem, 70a 4-5. 
mema entre los silogismos, Aristóteles está destacando la relación vinculante que existe entre retórica y hermenéutica ${ }^{44}$.

Ahora bien, si esto es así y más allá de la beligerante postura platónica, ¿cómo puede Gadamer compartir la idea de que existe una barrera infranqueable entre retórica y dialéctica? Está claro que para poder responder cabalmente a esta pregunta se hace necesario atender a las diferencias que las hacen irreductibles. Porque lo cierto es que, de acuerdo con Aristóteles y a pesar de su proximidad, retórica y dialéctica no se pueden identificar ${ }^{45}$. Al sostener que ambas son antistrofficas, el autor de la Retórica está afirmando que son análogas, pero a la vez está manteniendo su diferenciación: la especificidad de cada una de ellas ${ }^{46}$. Quizá el examen de las diferencias entre ambas contribuya a discernir con una cierta claridad las razones que tiene Gadamer para separarlas de un modo tan drástico.

Pues bien, para comenzar hay que tener en cuenta que, siempre según Aristóteles, aquello que es objeto de reflexión por parte del retórico y del dialéctico es diferente. Lo propio de la retórica «es reconocer lo convincente y lo que parece ser convincente, del mismo modo que [corresponde] a la dialéctica reconocer el silogismo y el silogismo aparentes ${ }^{47}$.

En segundo lugar es preciso recordar que, según Aristóteles, el retórico delibera siempre dentro del ámbito propio de la razón práctica; es decir, delibera sobre aquellas cosas - bienes o males- cuyo principio somos nosotros mismos y que, por lo tanto, no son necesarias ${ }^{48}$. Por el contrario, el Estagirita caracteri-

44 "En general, todo silogismo se construye a partir de enunciados y el enthymema no es más que un silogismo que se compone de los enunciados dichos". ARISTOTELES, Retorica I, 3.3, 1359a 8-11. Cfr. también Analiticos segundos I, 1 y Q. RACIONERO, "Introducción" a la Retórica, nota 16, en I, 1.4 .

${ }^{45}$ Cfr. ARISTOTELES, Refutaciones sofisticas 34, 183b 1-8, donde se confirma este particular.

${ }^{46}$ Cfr. ARISTÓTEles, Retórica, I, 4.1, 1359b 9-16.

47 Cfr. ibidem, 1355b, 15-21; el subrayado es mío.

48 "Ante todo, se ha de establecer sobre qué bienes o males delibera el que hace un discurso deliberativo, puesto que no cabe deliberar sobre cualquier cosa, sino sólo sobre lo que puede suceder o no, habida cuenta que no es posible ninguna deliberación sobre lo que necesariamente es o será o sobre lo que es imposible que exista o llegue a acontecer. Incluso no cabe deliberar acerca de todos los posibles. Porque, de entre los bienes que pueden suceder o no, hay algunos que acaecen o por naturaleza o por suerte, respecto de los cuales en nada aprovecha la deliberación. Resulta evidente, en cambio, sobre qué cosas es posible deliberar. Éstas son las que se relacionan pro- 
za la dialéctica - que en ocasiones asimila explícitamente a la crítica-como una capacidad de razonar acerca de cosas plausibles ${ }^{49}$. Así pues, lo propio del dialéctico no es la deliberación, puesto que ésta tiene que ver con la acción, sino más bien la reflexión y la argumentación relativas a cuestiones teóricas; de hecho, como ha expresado gráficamente Racionero, la dialéctica es el negativo de la ciencia $^{50}$. Que, en efecto, ésta es la comprensión aristotélica lo certifica un pasaje de la Metafisica bien conocido: "Los dialécticos discuten acerca de todas las cosas -y lo que es constituye lo común a todas las cosas-y discuten, evidentemente, acerca de tales cosas porque son el asunto propio de la filosofía, ${ }^{51}$.

Precisamente ahora y teniendo en cuenta el tipo de cuestiones que están motivando este trabajo, cabría preguntarse cuál es ese asunto propio de la filosofia o, planteado de otro modo, si las cuestiones de razón práctica son o no asunto propio de la filosofía. En cualquier caso, parece claro que Aristóteles (y más todavía en el texto concreto que se acaba de citar) está entendiendo la filosofía en el preciso sentido de sophía; esto es, como teoría y que, en consecuencia, está situando la dialéctica en el terreno de la reflexión teórica y no en el de la práctica. Esto se confirma si recordamos que, como declaró al principio de Tópicos, el propósito que guiaba ese estudio era encontrar en la dialéctica «un método a partir del cual podamos razonar sobre todo problema que se nos proponga, a partir de cosas plausibles" ${ }^{52}$. Ahora bien, razonar sobre cualquier problema es una actividad tan estrictamente teórica como lo es la propia de la filosofía. Así pues, hay que subrayar que, tal como lo entendió el Estagirita, lo que diferencia a la retórica de la dialéctica es que, como también señaló Aubenque, esta última es la lógica de lo verosímil. Por eso, en el mismo tratado al que se acaba de hacer referencia, cuan-

piamente con nosotros y cuyo principio de producción está en nuestras manos. Y, por eso, especulamos con cierta reserva hasta el instante en que descubrimos si [tales cosas] son posibles o imposibles de hacer por nosotros". Ibidem, I, 4.1, 1359a 30-1359b 2.

49 "Nos habramos propuesto, pues, encontrar una capacidad de razonar acerca de aquello que se nos planteara entre las cosas que se dan como plausibles; en efecto, ésta es la tarea de la dialéctica propiamente tal y de la crítican. ARISTOTELES, Refutaciones Sofisticas, 183a 37-183b.

50 "La dialéctica es un "negativo" de la ciencia; la retórica, un "negativo", de la ética y la politica". Q. RACIONERO, «Introducción" a la Retórica, op. cit., 130.

51 ARISTÓTELES, Metafisica IV, 1004b 19-21. Para lo relativo a las relaciones entre filosofia, dialéctica y sofistica cfr., entre otros, los siguientes lugares de la obra de ARISTÓTELES: Metafisica, XI, $1061 \mathrm{~b}$ 7-9; Refutaciones sofisticas, 171b, 28-37; Argumentos Sofisticos, 184 a 1-b 1.

${ }^{52}$ ARISTOTEles, Tópicos, 100a 19-20. 
do Aristóteles se está refiriendo a los diferentes tipos de razonamiento, precisa que «hay demostración cuando el razonamiento parte de cosas verdaderas y primordiales, o de cosas cuyo conocimiento se origina a través de cosas primordiales y verdaderas; en cambio es dialéctico el razonamiento construido a partir de cosas plausibles ${ }^{53}$.

Por otra parte, si hay algo que da cuenta del estatuto teórico de la dialéctica es el modo tan eminente en que Aristóteles la vincula con el conocimiento y/o descubrimiento de los primeros principios. Acerca de ellos dice que no cabe demostración, aunque sí la demostración dialéctica, la demostración refutativa ${ }^{54}$. Sostiene, además, que sólo se puede discurrir en torno a ellos a través de lo plausible y que esto es propio de la dialéctica ${ }^{55}$. Por último, el Estagirita afirma con rotundidad que «el principio de la demostración no es la demostración " ${ }^{56}$.

En los párrafos anteriores, de acuerdo con Aristóteles, he intentado dar cuenta sintética de las características por las que se distinguen retórica y dialéctica. $\mathrm{Al}$ hacerlo se ha ido poniendo de manifiesto algo en lo que, quizá por obvio, apenas nos detenemos. Se trata del carácter práctico que define a la retórica frente al teórico que caracteriza a la dialéctica. No cabe duda de que en el conjunto de la obra aristotélica hay explicaciones más que sobradas en este sentido, a las que, por otra parte, se ha hecho referencia al comienzo de este estudio. Sin embargo, el hecho de que esta discrepancia fundamental no se destaque siempre como definitoria de las diferencias cuando se las pone en relación, puede contribuir a que en algunos momentos pase desapercibida. De hecho, el asunto que centra nuestra atención cuando nos planteamos la relación de retórica y dialéctica es el que tiene que ver con el tipo de lógica que se despliega en un determinado tipo de discurso; advertimos que éste se puede mover en el plano de la persuasión o de la probabilidad; que puede estar orientado a conmover o a convencer, etc. Pero lo que quizá no observamos con tanta nitidez es que la dialéctica se sitúa, al menos

53 Ibidem, 100a 25-100b 18. Y uson cosas plausibles las que parecen bien a todos, o a la mayoría, o a los sabios, y, entre estos últimos, a todos, o a la mayoría, o a los más conocidos y reputados". Ibidem, 100b 22-3.

${ }^{54}$ Cfr. ARISTÓTEles, Metafisica IV, 1006a 12. Acerca de la imposibilidad de demostrar los primeros principios, cfr. también ARISTÓTELES, Analíticos segundos, I, 9.

"S5 Cfr. ARISTÓteles, Tópicos 101b 1-4.

${ }^{56}$ ARISTÓTELES, Analiticos segundos, $100 \mathrm{~b} 14$. 
según Aristóteles, en el mismo plano que la teoría. Quizá por ello, o al menos también por ello y de la mano de Platón, Gadamer encontrara una barrera infranqueable entre dialéctica y retórica, y es que no se puede olvidar que lo que el autor de Verdad y método está buscando es ese "saber que no es ciencia, pero que dirige la praxis de la vida humana" ${ }^{57}$.

En este orden de cuestiones, todavía hay algo más que señalar. En determinadas ocasiones, Gadamer parece ampliar los límites de la retórica más allá del discurso (al menos entendido en el sentido convencional del término); eso es lo que ocurre cuando apela a la comunicación intersubjetiva, entendida como la forma de comunicación que abarca tanto las modalidades del consenso tácito, como algunos fenómenos extralingüísticos pero comunicativos, tales como la risa y el llanto, a los que el autor de Verdad y método no duda en atribuir significado hermenéutico ${ }^{58}$. Además, tampoco se puede olvidar la apelación retórica a los afectos que, en opinión de nuestro pensador, no supone en modo alguno el abandono del ámbito de lo racional ${ }^{59}$.

Todo lo dicho viene a apuntalar la idea de que en el fenómeno del entendimiento, de la comprensión intersubjetiva, no sólo interviene el diálogo, el lenguaje, como sucedería en el caso de la dialéctica aristotélica, sino que habría, además, una comunicación no lingüística igualmente relevante. Pero con esto sólo tenemos una observación y una referencia a un fenómeno mucho más profundo y amplio en torno al cual ha girado enteramente el pensamiento de HansGeorg Gadamer. Se trata de «el fenómeno universal de la lingüisticidad humanas ${ }^{60}$.

Pero ya es el momento de volver a la pregunta formulada por Gadamer respecto a la naturaleza de ese saber que es la ciencia práctica y la política ${ }^{61}$. Páginas atrás se había respondido, con el pensador de Heidelberg, que se trataba de un saber general. Pero eso no es todo: el autor de Verdad y método advierte la necesidad de recordar que la filosofía práctica concebida por Aristóteles tiene tam-

57 H.-G. GADAMER, "Réplica a Hermenéutica y crítica de la ideología», op. cit, 243.

58 Cfr. H.-G. GADAMER, "Hermenéutica», op. cit, 369.

59 Cfr. H.-G. GADAMER, "Réplica a Hermenéutica y critica de la ideologia», op. cit, 263.

60 H.-G. GADAMER, "Retórica, hermenéutica y crítica de la ideología», op. cit., 226.

${ }^{61}$ Cfr. H.-G. GADAMER, "Réplica a Hermenéutica y critica de la ideologia», op. cit, 245. 
bién una dimensión teórica que le es esencial. Desde luego, se trata de un saber general que ni es identificable con el saber de la phrónesis - que se cumple exclusivamente en la acción-, ni tampoco, como ya se ha indicado, con el saber productivo. Sería, por el contrario y precisamente, crítica. Y, una vez más, esto mismo, como precisa Gadamer, es lo que sucede con la hermenéutica. Así pues, estaríamos llegando a la sorprendente conclusión de que la actividad propia de la hermenéutica - heredera y digna sucesora de la retórica filosófica - es la crítica. Pero, después de lo visto, ¿cómo podría ejercerla con independencia de la dialéctica? La respuesta, como tendremos oportunidad de estudiar a continuación, podría ser que esa función crítica se realiza, y además de manera radical, mediante la dialéctica de la pregunta y la respuesta en la que lo que es "refutado" (y aquí podríamos encontrar también una evocación de la kátharsis) es el alma del dialogante: «El diálogo socrático de signo platónico es sin duda un género muy especial de conversación que uno conduce y el otro tiene que seguir, quiera o no; pero es modelo de cualquier diálogo, porque en él no se refutan las palabras, sino el alma del otro" ${ }^{62}$.

Estas reflexiones últimas nos permiten responder también a la pregunta que, de la mano de Ricoeur, se ha planteado al comienzo de este epígrafe: ‘a qué tipo de dialéctica se está refiriendo Gadamer cuando la rechaza? La respuesta, como veremos de forma más detenida a continuación, es que Gadamer rechaza toda forma de dialéctica con pretensiones de constituirse en filosofia primera. Sin embargo, es necesario subrayarlo ya, esto no significa de ningún modo que reniegue de la dinámica dialéctica, sin la cual su propia postura y sus tesis principales no se podrían sostener.

Antes de pasar a analizar las cuestiones todavía pendientes, es preciso realizar un esfuerzo de recapitulación de lo que se ha estudiado a lo largo de este epígrafe. Como se ha recordado, Gadamer reclama para la hermenéutica filosófica el estatuto de saber de reflexión crítica; reivindica, además, una universalidad de la que estaría ausente la coacción. Fundamenta la universalidad del fenómeno hermenéutico en la correspondiente universalidad de la lingüisticidad humana; ahuyenta el peligro de la coacción acudiendo a la intención del filosofar. Además,

${ }^{62}$ H.-G. GADAMER, "Destrucción y deconstrucción", en Verdad y método Il, op. cit., pp. 349$62,357-8$. 
aparta de la hermenéutica filosófica la vinculación con la dialéctica que estaba presente en la retórica aristotélica; más allá de su inequívoca vinculación con $\mathrm{Pla}$ tón, el motivo de este rechazo estriba en que, a juicio de Gadamer, el proceso de entendimiento actúa a una mayor profundidad: en la esfera de la comunión intersubjetiva. Esto le permite acudir a la autoridad de un saber general como criterio último de discernimiento ${ }^{63}$.

No obstante, parece que la razón que en definitiva conduce a Gadamer al rechazo de la dialéctica es que ésta reproduce la dinámica presencialista de la metafísica occidental. De este asunto nos vamos a ocupar en el epígrafe siguiente.

\section{El giro hermenéutico: de la dialéctica monológica a la dialéctica del diálogo}

En «Destrucción y deconstrucción», Gadamer explica que su propuesta de partir de la conversación y del lenguaje común «abre una dimensión de entendimiento que trasciende los esquemas fijados linguísticamente y, por tanto, la síntesis omnicomprensiva en el sentido de la autocomprensión monológica de la dialéctica» ${ }^{64}$.

Como de hecho se comprueba unas líneas después, en este texto Gadamer está aludiendo directamente a la dialéctica hegeliana. No obstante, es necesario insistir en que no es tan sólo esta forma de dialéctica la que él pretende trascender. En realidad, en el rechazo de esa sintesis monológica y omnicomprensiva late su simultáneo rechazo de la metafísica que ha configurado la historia de la filosofía en Occidente hasta su reciente deriva en la ciencia moderna ${ }^{65}$. Que esto es así se pone de manifiesto al recordar qué es lo que en síntesis significa dialéctica

${ }^{63}$ Aunque éste no es el lugar para desarrollar esta cuestión, no se puede olvidar la advertencia vattimiana según la cual en la idea de conciencia común puede esconderse una «apologia de lo existente». Cfr. G. VATTIMO, "Verdad y retórica en la ontología hermenéutica», en El fin de la modernidad. Nihilismo y Hermenéutica en la cultura posmoderna, Gedisa, Barcelona, 1995.

${ }^{64}$ H.-G. GADAMER, "Destrucción y deconstrucción", 357.

65 "Lo verdaderamente significativo en el cambio que experimentó el concepto de ciencia al comienzo de la época moderna es que en medio de él persiste el enfoque fundamental de la idea griega del ser. La física moderna presupone la metafísica antigua (...). La ciencia es, por mucho que se la censure, el alfa y omega de nuestra civilización". H.-G. GADAMER, "¿Qué es la verdad", op. cit., 55. 
para Gadamer: «[Dentro del] amplio conjunto de la tradición occidental de la metafísica, tanto lo "lógico» en sentido hegeliano como el lógos del pensamiento griego, que marcó ya los primeros pasos de la filosofía occidental»" ${ }^{66}$. Está claro por tanto que, en opinión del precursor de la hermenéutica filosófica, la dialéctica constituye una expresión plena de la metafísica occidental. Pues bien, esta metafísica es rechazada por Gadamer debido a que, con Heidegger, la considera presencialista y, ahora de acuerdo con Derrida, logocentrista ${ }^{67}$. Por eso, su objetivo consiste en eliminar el lastre de la ontología de lo sustancial ${ }^{68}$, oponiéndose, a la vez, a cualquier forma de fijación de los conceptos (a lo que él denominó la beatería de los conceptos).

Gadamer entiende que sólo se han abierto dos vías para lograr una verdadera ruptura con la tradición occidental y para plantear, así, una alternativa a lo que él llamó la autodomesticación ontológica propia de la dialéctica. Uno de los caminos sería el de la deconstrucción, promovida por Derrida; el otro es precisamente el de la hermenéutica filosófica, que propone el retorno de la dialéctica al diálogo y de éste a la conversación ${ }^{69}$.

Por lo que se refiere a este asunto, Gadamer admite gustoso que la dialéctica de la pregunta y la respuesta, propugnada por él mismo, tiene su modelo en el diálogo socrático-platónico ${ }^{70}$. En la medida en que éste es capaz de trascender los esquemas fijados linguísticamente - $\mathrm{y}$, así, la primacía de la proposición y del presente-, se erige en su obligado punto de referencia. Tan es así que Gadamer llega a asimilar la dialéctica —entendida ahora en el preciso sentido de «el arte de llevar una conversación ${ }^{71}$ - con la hermenéutica, puesto que entiende que la tarea de esta última es la comunicación de sentido, y que es esto precisamente lo que el lenguaje realiza en el diálogo. A su vez, lo que se acaba de recordar le permite afirmar que "también el fenómeno hermenéutico encierra en sí el carácter original de la conversación y la estructura de la pregunta y la respuesta" ${ }^{72}$.

${ }^{66}$ H.-G. GADAMER, "Destrucción y deconstrucción», op. cit., 356.

${ }^{67}$ Ibidem.

68 Ibidem, 357.

69 Cfr. ibid., 355, y también "Autopresentación», op. cit., 400.

${ }^{70}$ Cfr. H.-G. GADAMER, «El modelo de la dialéctica platónica», en Verdad y Método I, Sígueme, Salamanca, 1997, 7. ${ }^{2}$ ed., trad., Ana Agud Aparicio y Rafael de Agapito, pp. 439-447.

71 Ibidem, 446.

${ }^{72}$ Ibidem, 447. Cfr. también, H.-G. GADAMER, "Autopresentación", op. cit., 402. 
Pero estaríamos equivocando el sentido y alcance del proyecto gadameriano si supusiéramos que ese retorno al diálogo constituye un simple retroceso desde la dialéctica hegeliana a la platónica. Por el contrario, Gadamer sostiene que el giro hermenéutico «apunta por detrás de este giro socrático-dialogal a su presupuesto: la anámnesis buscada y suscitada en los logoin ${ }^{73}$.

Desde luego, no se trata aquí de postular un retroceso al mito; por el contrario - yendo más atrás, o mejor, más a fondo - lo que Gadamer pretende, desde la conciencia de que "somos una conversación», es buscar el "espíritu capaz de unirnos" ${ }^{74}$. La exigencia de "salir de sí mismo, pensar con el otro y volver sobre sí mismo como otro" ${ }^{75}$ puede parecer a algunos desmedida o, quizá haya que admitirlo, carente de racionalidad. Pero también es posible pensar que la veneración racionalista por el método y la verificación adolezca de la racionalidad plena desde la que Gadamer realiza su propuesta.

La reivindicación gadameriana del diálogo se realiza desde la doble convicción de que somos en el lenguaje y de que éste no se agota ni se deja apresar en la proposición. Esto explica que, frente a la comprensión metafísica de la dialéctica, Gadamer proponga la dialéctica de la pregunta y la respuesta. Algo que, además, lleva a pensar que en realidad no se debería hablar de un rechazo indiscriminado de la dialéctica por parte de Gadamer, sino más bien de un modo radical y más originario de entenderla. De hecho, la vuelta al diálogo y al ejercicio de la anámnesis ha de ser, por fuerza, dialéctica. Quizá sea esto lo que explique el interés gadameriano por mostrar que también a juicio de Aristóteles ${ }^{76}$ "el saber es fundamentalmente dialécticon ${ }^{77}$ y que, por tanto, en el lenguaje y la búsqueda de la verdad la primacía corresponde a la pregunta y no al enunciado: «este es realmente el fenómeno hermenéutico primigenio: no hay ningún

73 H.-G. GADAMER, «Destrucción y deconstrucción», op. cit., 356.

74 Ibidem.

75 Ibidem.

76 Aristóteles afirma que la dialéctica es la capacidad de investigar los contrarios; cfr. ARISTOTELES, Metafisica XIII, 1078b 25ss; Tópicos, 105b 23. A partir de esta tesis aristotélica, Gadamer se permite extraer una conclusión fuerte: que también en Aristóteles la primacía es de la pregunta y, por tanto, no de la proposición.

77 «El saber es fundamentalmente dialéctico. Sólo puede poseer algún saber el que tiene preguntas, pero las preguntas comprenden siempre la oposición del sí y el no, del así y de otro modo". Verdad y Método I, op. cit., 442. 
enunciado que no se pueda entender como respuesta a una pregunta, y sólo así se puede entender" ${ }^{78}$.

A primera vista puede resultar sorprendente que precisamente en los momentos en que Gadamer quiere superar el primado del lógos apofántico, y con él de la proposición enunciativa, intensifique el diálogo con uno de sus máximos antagonistas y, no obstante, interlocutor permanente: Hegel. Pero lo cierto es que la crítica a la proposición realizada por este pensador es el camino que Gadamer elige para mostrar que la dialéctica ha de devenir hermenéutica. Ahora bien, para alcanzar cabalmente su objetivo, Gadamer ha de poner de relieve la profunda vinculación existente entre Aristóteles y Hegel; es decir, la continuidad existente entre los planteamientos griego y moderno. Como se intentará mostrar a continuación, el nexo inquebrantable de unión entre ambos es, según el autor de Verdad y método, el carácter esencial que para los dos pensadores ha detentado la idea de enérgeia entendida como presencia pura. Esto y no otra cosa es lo que, ya antes a juicio de Heidegger y ahora en opinión de Gadamer, ha causado la distorsión en la que parece haber surgido y consistido la metafísica occidental; aquélla en virtud de la cual se ha intentado descifrar lo finito con las claves de lo infinito y apresar la temporalidad extática dentro de los límites de un imposible presente puro.

Las dos cuestiones que se acaban de mencionar habrán de ser examinadas con cierto detenimiento. En primer lugar se abordará lo relativo a la vinculación entre el pensamiento hegeliano y el aristotélico. A continuación se habrá de estudiar el análisis de Gadamer sobre la crítica hegeliana de la proposición enunciativa.

Por lo que respecta al primer asunto, la vinculación entre Aristóteles y Hegel, hay que tener en cuenta unas precisiones mínimas, que el mismo Gadamer quiso poner de relieve. Ante todo, conviene recordar que la dialéctica griega lo es del movimiento y no de la autoconciencia ${ }^{79}$. Sin embargo, precisamente esto

${ }^{78}$ H.-G. GADAMER, «La universalidad del problema hermenéutico (1966)" en Verdad y método II, op. cit., pp. 213-24, 219.

79 Se trata de la dialécrica tal como aparece en Zenón o en el último Platón pues, como también afirma Gadamer, «en el fenómeno del movimiento cobra el espíritu certeza de su mismidad por primera vez». H.-G. GADAMER, "Hegel y la dialéctica de los filósofos griegos», en La dialéctica de Hegel, Cátedra, Madrid, 1979, trad., Manuel Garrido, pp. 11-48, 22. 
resulta central para entender la identidad, en medio de la diferencia, de los dos grandes pensadores que nos están ocupando ahora. Fue el mismo Hegel quien afirmó que la dialéctica del movimiento reclamaba su continuidad en la dialéctica del espíritu y quien entendió que aquélla proporcionaba un modelo para su propio método dialéctico ${ }^{80}$. Es cierto que Gadamer insistió en varias ocasiones en la modernidad de Hegel; sin embargo, esto no le impidió admitir la pertinencia de la pretensión de aquél de haber reincorporado la filosofía griega a su ciencia especulativa ${ }^{81}$. De hecho, en "La idea de la lógica de Hegel», Gadamer insiste en que para entenderla es preciso retrotraerse a la filosofía griega. En concreto, Gadamer sostiene que Hegel «restaura el saber absoluto como verdad de la metafísica, a la manera, por ejemplo, como pensó Aristóteles el noûs o Tomás el intellectus agens (...). Su concepto de espíritu (...) se retrotrae, por tanto, a la metafísica del lógos/noûs de la tradición platónico-aristotélica " ${ }^{82}$. Una metafísica que, como ya se ha mencionado líneas atrás, tiene su núcleo y cúspide en la idea griega de enérgeia.

Lo que llevamos analizado hasta el momento se puede resumir en dos tesis: la primera es que la dialéctica griega es la dialéctica del movimiento; la segunda, que el saber absoluto hegeliano se retrotrae a la metafísica aristotélica del nô̂s. Pero lo que importa aquí no es volver a recordar lo que es sobradamente conocido. Lo que resulta relevante es analizar el modo en que aquella dialéctica del movimiento se puede enlazar, y más aún reencontrar, en la dialéctica de la autoconciencia. Pues bien, la explicación que proporciona Gadamer tiene su origen en la crítica heideggeriana a la metafísica de la presencia. Según el joven pensador de Friburgo, Aristóteles llegó a la idea de enérgeia como consecuencia de una radicalización ontológica de la idea de movimiento ${ }^{83}$. Gadamer, por su parte, insis-

${ }^{80}$ Cfr. ibidem, 24-6.

81 «Por mucho que esté determinado por el punto de partida de la filosofía moderna, según el cual lo absoluto es vida, actividad, espíritu, no es, sin embargo, en la subjetividad de la autoconciencia donde ve Hegel el fundamento de todo saber, sino en la racionalidad de todo lo real, y, por ende, en un concepto de espíritu como lo verdaderamente real. Ello sitúa netamente a Hegel dentro de la tradición de la filosofía griega del nồs, que comienza con Parménides». H.-G. GADAMER, «Hegel y la dialéctica de los filósofos griegos", op. cit., 21. 108,79 .

H.-G. GADAMER, "La idea de la lógica de Hegel», en La dialéctica de Hegel, op. cit., pp. 75-

${ }^{83}$ Cfr. C. Segura, Hermenéutica de la vida humana. En torno al "Informe Natorp» de Martin Heidegger, Trotta, Madrid, 2002. 
tió en esta interpretación afirmando que "el concepto de enérgeia, que Aristóteles concibe como pura presencia, es, sin duda, originariamente un concepto de movimiento" " añadió, además, que ese concepto "significa la pura presencia como tal, que, en su pureza, conviene al motor inmóvil, al noûs, a la razón" ${ }^{85}$. Desde luego, no cabe duda de que Aristóteles concibió a Dios como una sustancia perfecta de la que el cambio está totalmente ausente - más aún, se podría sostener que el Dios aristotélico es la misma negación de cambio: el motor que sin moverse mueve-; una sustancia, por último, que es vida nobilísima y que, por lo tanto, se ha de concebir como nóesis noéseos nóesis, es decir, como enérgeia. Cómo a partir de aquí se puede vincular la dialéctica del movimiento con la de la autoconciencia es algo que ya no ofrece dificultades. Desde luego, a juicio de Gadamer la explicación es bien sencilla: Hegel reinterpreta a Aristóteles desde su propia situación; es decir, desde el descubrimiento moderno de que el absoluto es espíritu y vida ${ }^{86}$.

No hay duda respecto a las dificultades que plantea la autovinculación de Hegel con el pensamiento griego y, en concreto, con el aristotélico. El autor de Verdad y método sostiene abiertamente que la comprensión e interpretación hegeliana de Aristóteles no siempre fue fiel al pensamiento de este último. Para mostrarlo, Gadamer remite al estudio llevado a cabo por Hegel en sus Lecciones sobre filosofia de la historia, donde aborda algunos pasajes de tercer libro del De Anima. Su análisis (en el que no nos podemos detener ahora) le permite llegar a la conclusión de que Hegel introduce algunas modificaciones, esenciales por cierto, en la filosofía del Estagirita y que son éstas las que le permiten llegar a una conclusión no aristotélica: que lo que es supremo es el ser del pensamiento, su libre actividad. Sin embargo, sólo en opinión de Gadamer, está claro que para Aristóteles lo que es primero es lo pensado. Ahora no es momento para detenernos en análisis de orden interpretativo-historiográfico ${ }^{87}$. Lo que importa es

${ }^{84}$ H.-G. GADAMER, «Hegel y la dialéctica de los filósofos griegos», op. cit., 23.

85 Ibid.

${ }^{86}$ Cfr. ibid., 40-3.

87 En cualquier caso, la afirmación gadameriana de que para Aristóteles lo primero es lo pensado resulta discutible. En el libro XII de la Metafisica el Estagirita afirma lo siguiente: «El entendimiento se capta a sí mismo captando lo inteligible, pues deviene inteligible al entrar en contacto con lo inteligible y pensarlo, de modo que entendimiento e inteligible se identifican" (1072b 19ss, los subrayados son míos). Entiendo que quizá sea este texto el que permite llegar a la interpretación de Gadamer, sobre todo en sus primeras líneas; sin embargo, no se puede ignorar que la con- 
señalar con claridad cuáles fueron las razones que permitieron a Hegel continuar la dialéctica del movimiento en la de la autoconciencia. Las que se acaban de destacar nos permiten comprender que la concepción hegeliana del absoluto arraiga en la aristotélica del noûs y que, por tanto, también en ambas el criterio presencial (por decirlo con Heidegger) continúa siendo rector.

Pero está claro que Gadamer no puede admitir una dialéctica que hunde sus raíces en las ideas de noûs y enérgeia. Como es sabido, el autor de Verdad y método insiste de manera constante en que los seres humanos, en cuanto finitos e históricos, nada tenemos que ver con esa idea de un pensamiento puro. Por eso es evidente, como también se ha sugerido antes, que la única dialéctica que Gadamer puede defender es la platónica inserta en la dinámica de la pregunta y la respuesta que, por su propia índole, se sitúa en las antípodas de aquellas concepciones, la aristotélica y la hegeliana, que han sido en el alfa y el omega de la metafísica occidental.

Ahora bien, la defensa del diálogo como alternativa capaz de trascender el presencialismo reclama la crítica del lógos apofántico, del enunciado como lugar exclusivo y privilegiado en el que se da la verdad. Por otra parte, ya al comienzo de este epígrafe, se ha sostenido que lo que en definitiva habría de servir a Gadamer para mostrar que la dialéctica debía devenir hermenéutica, sería la crítica de Hegel a la proposición. Lo que justifica esta afirmación es que, a juicio de Gadamer, la crítica dialéctica al enunciado protagonizada por el autor de la Ciencia de la lógica continúa dentro del ideal griego; ésta abocaría a un ideal de

clusión final del mismo es que "entendimiento e inteligible se identifican" y que, por tanto, no se podría hablar de una prioridad de lo pensado respecto del pensamiento o del pensamiento con relación a lo pensado. También habría que tener en cuenta que, unas líneas después, Aristóteles continúa diciendo que uen él [Dios] hay vida, pues la actividad del entendimiento es vida y él se identifica con tal actividad. Y su actividad es, en sí misma, vida perfecta y eterna" (ibidem, 26-28, los subrayados son míos). La afirmación de que Dios es actividad avala la idea de que es ésta, la actividad, lo único que se puede considerar primero y que para el Estagirita ésta implica por igual al pensamiento y a lo pensado. Por último, la comprensión aristotélica no ofrece dudas cuando en el capítulo 9 del mismo libro afirma lo siguiente: «Por otra parte, si piensa, pero para ello depende de otra cosa (...), entonces no sería ya la entidad más perfecta: en efecto, la excelencia le viene del acto de pensar (...). Además, es obvio que lo más excelso sería otra cosa en vez del pensamiento: lo pensado (...). Por consiguiente, si es la cosa más excelsa, se piensa a sí mismo y su pensamiento es pensamiento de pensamiento" $(1074 \mathrm{~b}, 1834)$. Agradezco a la prof. Claudia Carbonell sus consideraciones a este respecto. 
enunciación total, que se constituiría así como la radicalización del planteamiento griego $^{88}$.

Pero veamos esta cuestión con cierto detenimiento. Hegel crítica la proposición por considerarla un vehículo inadecuado para la esencia especulativa de la filosofía. En opinión de Gadamer, está claro que la proposición no puede satisfacer a un pensador que entiende que la exigencia de la filosofía es concebir. Así es, en la medida en que el sujeto de la proposición es determinado por predicados que le son externos, falta la necesidad del desarrollo exigida por Hegel, y el pensamiento no se atiene a la cosa. Resulta palmaria, por tanto, la necesidad hegeliana de rechazar el pensamiento representativo y de acudir a las proposiciones filosóficas: en ellas, el predicado ya no se constituye como algo diferente del sujeto sino que es la expresión del continuo ahondar en el sujeto $^{89}$.

Aunque las razones que mueven a uno y otro a rechazar la proposición enunciativa son bien diferentes, Gadamer coincide con Hegel en que «la forma de la proposición no tiene ninguna justificación filosófica dentro del propio cuerpo de la ciencia filosófica ${ }^{90}$. Es decir, entiende que si la dialéctica del absoluto puede erigirse en forma de la demostración filosófica, ello es porque «las proposiciones de la filosofía no pueden ser entendidas como juicios en el sentido de la lógica predicativa" ${ }^{91}$. Es más, Gadamer llega a añadir que «esto es también válido para Aristóteles, a pesar de que haya sido Aristóteles quien explicó la estructura de la predicación, tanto en su forma lógica como en su fundamento ontológico»" ${ }^{22}$. Pero en realidad y a pesar de los esfuerzos hegelianos, Gadamer entiende que en último extremo Hegel no hace sino radicalizar la tradición aristotélica que concede la primacía al logos apofántico, «no sólo con ayuda de la dialéctica, sino, sobre todo, al traer a concepto, en su Lógica, la propia estructura lógica de la dialéctica ${ }^{93}$.

\footnotetext{
Cfr. H.-G. GaDAmeR, "¿Qué es la verdad?", op. cit., 58.

89 Cfr. H.-G. Gadamer, «Hegel y la dialéctica de los filósofos griegos», op. cit., 26-30.

90 Ibidem, 47.

91 Ibidem, 44.

92 Ibidem.

${ }^{3}$ H.-G. GADAMER, "La idea de la lógica en Hegel», op. cit., 98. Además: «la idea de la lógica de Hegel remite hacia más allá de sí misma, puesto que la expresión "lo lógico", tan del gusto de Hegel, reconoce la real imposibilidad de que sea completado el concepto». Ibidem, 102.
} 
Ésta es la razón de que, a juicio de Gadamer, el límite puesto por Hegel a la lógica del enunciado no se pueda definir desde él y de que, al mismo tiempo, se haga preciso recurrir a las ciencias de la experiencia histórica, que se imponen contra Hegel ${ }^{94}$. Más en concreto, ésta sería la razón que explicaría en última instancia la necesidad de recurrir a la propuesta gadameriana de una hermenéutica próxima a la vieja retórica aristotélica. Y es que, en opinión de Gadamer, no es el concepto sino el lenguaje lo que permite superar el esquema de la proposición. Por eso sostiene que "entre la tautología y la autoanulación en la infinita determinación de su sentido, la proposición especulativa se mantiene en el punto medio».

Es aquí donde reside la principal actualidad de Hegel: «La proposición especulativa no es tanto enunciado como lenguaje" ${ }^{95}$. Esto último es lo que, a todas luces, interesa subrayar a Gadamer. De hecho, cuando de lo que se trata es de destacar el carácter especulativo del lenguaje, la valoración gadameriana de Hegel varía de manera notable ${ }^{96}$; más todavía, parece que Gadamer se atreve a leer a Hegel desde sus propias convicciones hermenéuticas. Así por ejemplo, el autor de Verdad y método afirma que en el propósito hegeliano de hacer fluidas las determinaciones del pensar se esconde el empeño por reconducir la lógica al lenguaje; por otra parte, sostiene también que "la dialéctica hegeliana es un monólogo del pensar que intenta producir por adelantado lo que poco a poco va madurando en cada conversación auténtica, ${ }^{97}$. Todo esto es lo que le permite afirmar que incluso en el fracaso hegeliano se puede encontrar un recuerdo grandioso de lo que era y es la dialéctica.

Lo que en último extremo está pensando Gadamer es que la ansiada lógica del concepto - con la que Hegel pretendía superar las limitaciones de la proposición- a lo que conduce realmente es a la lógica natural del lenguaje ${ }^{98}$. Por eso,

94 Cfr. H.-G. GaDAMER, “QQué es la verdad?», op. cit., 58.

95 H.-G. GaDAMER, "La idea de la lógica en Hegel», op. cit., 102-3.

96 Cfr. H.-G. Gadamer, "Hegel y la dialéctica de los filósofos griegos", op. cit., 45-8. También: "podemos dar a lo que es común a la dialéctica metafísica y a la hermenéutica el nombre de especulación». H.-G. GADAMER, Verdad y Método I, op. cit., 557.

${ }^{97}$ H.-G. GADAMER, Verdad y Método I, op. cit., 447.

98 «No apunta necesariamente, por su parte, la lógica del concepto que se autodespliega hacia más allá y por detrás de sí misma, a saber, hacia la "lógica natural" del lenguaje?». H.-G. GADAMER, "La idea de la lógica en Hegel», op. cit., 106-7. 
la monografía gadameriana sobre la idea de la lógica en Hegel concluye con las siguientes palabras:

En el carácter lingüístico de todo pensamiento se alberga una exigencia en contraria dirección que transmuta el concepto en palabra vinculante. Cuanto más radicalmente medita sobre sí el pensamiento objetivante y despliega la experiencia de la dialéctica, tanto más claramente remite a lo que él no es. La dialéctica ha menester de reducirse a hermenéutica ${ }^{99}$.

Un movimiento en dirección contraria a la que imprime el ansia de la pura manifestación, el deseo de demostración y el anhelo - desesperadamente humano- de certeza. Transmutar el concepto en palabra vinculante es el camino elegido por Gadamer para alcanzar una sabiduría humana que, frente a la ciencia, es nesciencia, pero que, paradójicamente, podría conducir a un saber de reflexión crítica. La elección puede parecer arriesgada y, seguramente, lo es.

\section{Algunas conclusiones provisionales}

Es preciso admitir que los desarrollos realizados por Gadamer para mostrar la viabilidad de su alternativa no han resultado suficientes para despejar todas las dudas de los escépticos ni todas las críticas de sus oponentes. De cualquier modo, como se ha intentado mostrar en esta investigación, la reivindicación gadameriana de la retórica no está hecha ni desde la ingenuidad ni desde el menosprecio de la tarea crítica. Lo que sucede es que el autor de Verdad y método parte de una convicción básica: la relativa a la universalidad de la lingüisticidad humana. En mi opinión, no se trata tanto de que Gadamer quiera arrogarse, en beneficio de la hermenéutica filosófica, tal universalidad; se trata, más bien, de que advierte la necesidad de contar con algo que ya de antemano es así para situar la problemática filosófica, científica y crítica en su justo lugar.

El autor de Verdad y método - un trabajo que modificó de modo esencial el panorama filosófico de la segunda mitad del siglo $\mathrm{XX}$ - se comprometió con la finitud del ser humano y con el carácter situacional de su razón. Desbancó pre- 
tensiones grandes e incluso gloriosas, aunque también extremadamente peligrosas. Su reivindicación de la razón práctica, del discurso y el diálogo, de la dialéctica de la pregunta y la respuesta constituye, ante todo, una invitación para seguir adelante. La dinámica dialéctica forma parte, de un modo inapelable, de nuestro modo de ser humano y filosófico. Como se ha intentado mostrar, el intento de Gadamer no consistió tanto en erradicar la dialéctica cuanto en situarla en su dimensión más auténtica y fecunda. Quizá la superación de la diferencia no sea lo último ni lo mejor; el reconocimiento de la diversidad exige renuncias: pasa por la aceptación de que el ser humano no se compadece con el absoluto.

En realidad, lo que se ha pretendido mostrar a lo largo de estas páginas es que Gadamer entendió la crítica como refutación. Desde luego, ésta no forma parte del método científico tal como lo hemos concebido y establecido desde Descartes. No obstante, parece bastante claro que para alcanzar el saber sobre los verdaderos fines de la sociedad humana hace falta algo más que experimentación y posibilidad de repetición. Hay que tener además en cuenta que lo que es bueno y mejor para todos no se impone: se conquista en medio de la confrontación, pacífica y desinteresada, en la que consiste la conversación. Ahora bien, no se puede olvidar que nos hallamos frente a un reto: el que supone admitir que la posibilidad del diálogo pasa por la necesidad —que es menester asumir sin reservas- de soportar, como el otro, la refutación del alma. 